\title{
Assessment of phytochemicals, antioxidant, anti-lipid peroxidation and anti-hemolytic activity of extract and various fractions of Maytenus royleanus leaves
}

\author{
Maria Shabbir ${ }^{\dagger}$, Muhammad Rashid Khan ${ }^{*}$ and Naima Saeed ${ }^{\dagger}$
}

\begin{abstract}
Background: Maytenus royleanus is traditionally used in gastro-intestinal disorders. The aim of this study was to evaluate the methanol extract of leaves and its derived fractions for various antioxidant assays and for its potential against lipid peroxidation and hemolytic activity.

Methods: Various parameters including scavenging of free-radicals (DPPH, ABTS, hydroxyl and superoxide radical), hydrogen peroxide scavenging, $\mathrm{Fe}^{3+}$ to $\mathrm{Fe}^{2+}$ reducing capacity, total antioxidant capacity, anti-lipid peroxidation and anti-hemolytic activity were investigated. Methanol extract and its derived fractions were also subjected for chemical constituents. LC-MS was also performed on the methanol extract.

Results: Qualitative analysis of methanol extract exhibited the presence of alkaloids, anthraquinones, cardiac glycosides, coumarins, flavonoids, saponins, phlobatannins, tannins and terpenoids. LC-MS chromatogram indicated the composition of diverse compounds including flavonoids, phenolics and phytoestrogens. Methanol extract, its ethyl acetate and $n$-butanol fractions constituted the highest amount of total phenolic and flavonoid contents and showed a strong correlation coefficient with the $\mathrm{IC}_{50}$ values for the scavenging of $\mathrm{DPPH}$, hydrogen peroxide radicals, superoxide radicals, anti-lipid peroxidation and anti-hemolytic efficacy. Moreover, $n$-butanol fraction showed the highest scavenging activity for ABTS radicals and for reduction of $\mathrm{Fe}^{3+}$ to $\mathrm{Fe}^{2+}$.

Conclusions: Present results suggested the therapeutic potential of Maytenus royleanus leaves, in particular, methanol extract, ethyl acetate and $n$-butanol fraction as therapeutic agent against free-radical associated damages. The protective potential of the extract and or fraction may be attributed due to the high concentration of phenolic, flavonoid, tannins and terpenoids.
\end{abstract}

Keywords: Maytenus Royleanus, Antioxidant Activities, Phenolic Content, Solvent Extraction

\section{Background}

Nowadays, plants provide raw materials for new sources of drugs and pharmaceutical products. A wide variety of naturally occurring constituents such as polyphenolics, terpenoids and pro-vitamins have received much attention as alternative therapeutic agents to fight against various oxidative stress induced diseases [1-3]. Numerous natural antioxidants from medicinal plants have

\footnotetext{
* Correspondence: mrkhanqau@yahoo.com

${ }^{\dagger}$ Equal contributors

Department of Biochemistry, Faculty of Biological Sciences, Quaid-i-Azam University Islamabad, Islamabad 45320, Pakistan
}

been isolated and characterized. In particular, phenolic compounds are suggested to exert therapeutic activities because of their anti-oxidative and anti-inflammatory properties. The polyphenolic compounds impart multiple antioxidant properties such as scavenging of free radicals, reducing abilities or act as metal chelators. Furthermore, anti-microbial, anti-thrombotic and vasodilator properties of phytochemicals have increased the interest as alternative and complementary medicines [4]. The ability of cells to detoxify the reactive intermediates that are produced as a result of excessive metabolism is compromised, which disturbs the equilibrium between

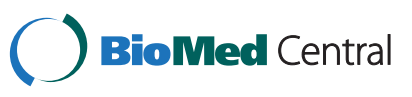


antioxidant and reactive oxygen species (superoxide radical, hydroxyl radical, peroxide radical, and nitric oxide). In addition to the threats posed by oxidative stress to biological system, it is also responsible for inducing chronic diseases (cancer, cardiovascular, aging, diabetes, cataract) [5]. Various studies have suggested an association between the dietary intake of these phytochemicals and the prevention of various stress induced anomalies [6-11]. It is need of the day that medicinal plants should be characterized for their pharmacological properties as majority of the population in developing countries use traditional medicines [11-13].

Antioxidants (polyphenols, vitamin $\mathrm{C}$, vitamin $\mathrm{E}$, selenium, $\beta$-carotene, lycopene, lutein and other carotenoids) present in large amounts in many medicinal plants and herbs, eliminate free radicals by acting as antioxidant, by neutralizing, quenching, reducing or through decomposing peroxides [14]. Compounds carrying antioxidant potential can be isolated and used as a remedy against oxidative stress and related diseases [15]. Recent studies are focusing on replacement of synthetic antioxidants with naturally occurring antioxidants to avoid the potential toxicity of synthetic ones [16-18].

Maytenus royleanus belongs to the family Celastraceae, Its flowering season is March-April and is distributed throughout lower Kaghan on dry sunny slopes. It is a shrub having stiff branches, usually with straight thorns, white flowers in short axillary clusters, fruit is 3 angled capsule [19]. Paste of bark is applied with mustard oil to destroy pediculi and it is also used locally against gastro-intestinal diseases [20]. Smoke of the seeds is believed to be valuable against toothache. Leaves are often used as fodder. Branches are used for repair of houses and fuel. In spite of the popular use, there is no report about phytochemical composition and antioxidant properties of $M$. royleanus leaves. Involvement of oxidative stress as a key role in various diseases, we aimed to evaluate the phytochemical and antioxidant potential of this plant.

\section{Methods}

\section{Chemicals}

All the chemicals used in these assays were of high quality. $\mathrm{Na}_{2} \mathrm{CO}_{3}$, ascorbic acid, gallic acid, rutin, FolinCiocalteu's phenol reagent, $\mathrm{NaNO}_{2}, \mathrm{AlCl}_{3} \cdot 6 \mathrm{H}_{2} \mathrm{O}$, rutin, 2, 2-Diphenyl-1-Picrylhydrazyl (DPPH), 2,2- azino-bis (3-ethylbanzthiazoline-6- sulphonic acid (ABTS), potassium oxidopersulphate, $\mathrm{H}_{2} \mathrm{SO}_{4}$, ammonium molybdate, riboflavin, phenazine methosulphate (PMS), nitroblue tetrazolium (NBT), $\mathrm{H}_{2} \mathrm{O}_{2}$, 2- deoxyribose, ferric chloride, potassium chloride, trichloroacetic acid (TCA), thiobarbituric acid (TBA), potassium ferricynide, Mayer's reagent, $\mathrm{NaOH}, \mathrm{FeCl}_{3}$ were obtained from Sigma
Chemicals Co. (St. Louis, MO, USA). Solvents and other reagents were of analytical grade.

\section{Collection of plant}

Collection of the plant material was made in March 2011 from village Lehtrar, Tehsil Kotli Sattian of Pakistan. After identification a voucher specimen (\# 032564) was deposited at the Herbarium of Pakistan Museum of Natural History, Islamabad.

\section{Preparation of extract}

Powder of dried leaves (500 g) was extracted with 95\% methanol twice (2000 ml for each) for $48 \mathrm{~h}$ with occasional shaking and filtered. Extract was dried at $40^{\circ} \mathrm{C}$ under reduced pressure giving a yield of $12.2 \%$ to that of the powder (Panchun Scientific Co., Kaohsiung, Taiwan). Extract was suspended in $50 \mathrm{ml}$ of distilled water and fractions were made by adding solvents (200 ml twice) successively with increasing polarity i.e., $n$-hexane, chloroform, ethyl acetate, $n$-butanol and shake vigorously. The layers were separated accordingly and the soluble remainder was used as residual aqueous fraction. Fractions were dried with the yields $n$-hexane $(7.5 \%)$, chloroform (3.4\%), ethyl acetate (8.9\%), $n$ - butanol $(7.8 \%)$ and residual aqueous fraction $(10.7 \%)$ to that of the methanol extract [21].

\section{Phytochemical screening}

The methanol extract of $M$. royleanus was analyzed by LC-MS to get the fingerprint of compounds it carries and was found to carry number of compounds (retention time: $0.5-45 \mathrm{~min}, \mathrm{~m} / \mathrm{z}$ "mass" restriction: 100-3200 $\mathrm{Da}$, peak height $>500$ counts, relative height: $>2.5 \%$, limit to largest: 300 compounds). Dried sample of methanol extract $(\sim 15 \mathrm{mg})$, was dissolved $1 \mathrm{ml}$ of methanol $(15 \mathrm{mg} / \mathrm{ml})$. It was spun down to remove particles and $10 \mu \mathrm{l}$ was injected under $\mathrm{C} 18$ or HILIC chromatography and positive (C18) or negative (C18/HILIC) ionization (targeting flavonoids and phenolic acids).

\section{Qualitative determination of the chemical constituents}

Presence of alkaloids, anthraquinones, cardiac glycosides, coumarins, flavonoids, saponins, phlobatannins, tannins and terpenoids in the extract and various fractions was confirmed individually by following standard procedures.

\section{Test for alkaloids}

Mixture of methanol extract of $M$. royleanus leaves and its various derived fractions $(0.4 \mathrm{~g})$ in $8 \mathrm{ml}$ of $1 \% \mathrm{HCl}$ was warmed on water bath. After filtration $2 \mathrm{ml}$ filtrate from the extract and each fraction was allowed to react with few drops of potassium mercuric iodide and with potassium bismuth, separately. Turbidity or precipitation 
formation was considered as a confirmation for presence of alkaloids [22].

\section{Test for saponins}

The criterion of oil emulsion formation of saponins was used for the screening of saponins [22]. Briefly, extract and various fractions (20 mg) suspended in $20 \mathrm{ml}$ of distilled water and boiled for $5 \mathrm{~min}$. In $10 \mathrm{ml}$ of the above filtrate $5 \mathrm{ml}$ of distilled water was added and mixed well to develop the froth. Development of emulsion after mixing the froth with olive oil confirmed the existence of saponins.

\section{Test for terpenoids}

Briefly, $2 \mathrm{ml}$ of chloroform was mixed with $5 \mathrm{ml}(1 \mathrm{mg} /$ $\mathrm{ml}$ ) of each sample in a test tube then $3 \mathrm{ml}$ of concentrated $\mathrm{H}_{2} \mathrm{SO}_{4}$ was added to develop the color. Exhibition of reddish brown coloration at the interface confirmed the presence of terpenoids [22].

\section{Test for anthraquinones}

To a volume of $6 \mathrm{ml}$ of $1 \% \mathrm{HCl}, 200 \mathrm{mg}$ of each sample was added separately and boiled. Benzene $(5 \mathrm{ml})$ was mixed with the filtrate and after separation of benzene layer $2 \mathrm{ml}$ of $10 \%$ ammonia solution was lowered. Development of pink, violet or red color in the ammonical phase indicated the existence of anthraquinones [22].

\section{Cardiac glycosides determination}

An aliquot of $5 \mathrm{ml}$ of methanol extract of $M$. royleanus leaves and its various fractions $(10 \mathrm{mg} / \mathrm{ml}$ in methanol) were added in the sequence of glacial acetic acid $(2 \mathrm{ml})$ and $\mathrm{FeCl}_{3}$ solution (one drop). Concentrated $\mathrm{H}_{2} \mathrm{SO}_{4}$ $(1 \mathrm{ml})$ was added and the formation of brown ring at the interface confirmed the presence of cardiac glycosides [23].

\section{Test for coumarins}

In a vial having $300 \mathrm{mg} / \mathrm{ml}$ of the extract and each fraction was plugged with filter paper dipped in $1 \mathrm{~N} \mathrm{NaOH}$ and boiled in a boiling water bath for few minutes. Yellow fluorescence of filter paper under UV light confirmed the presence of coumarins [23].

\section{Test for phlobatannins}

An amount of $80 \mathrm{mg}$ of the extract and various fractions was boiled in $1 \% \mathrm{HCl}$. Development of red precipitate indicated the existence of phlobatannins [23].

\section{Test for flavonoids}

Mixture of methanol extract and various fractions of $M$. royleanus leaves were prepared by adding $50 \mathrm{mg}$ of each sample to $100 \mathrm{ml}$ of distilled water and filtered. An aliquot of $5 \mathrm{ml}$ of dilute ammonia solution was mixed with
$10 \mathrm{ml}$ of the filtrate. Appearance of yellow coloration by addition of few drops of concentrated sulfuric acid indicated the presence of flavonoid [24].

\section{Test for tannins}

A mixture was prepared by mixing $50 \mathrm{mg}$ of methanol extract and each fraction in $20 \mathrm{ml}$ of distilled water and boiled. Appearance of brownish green or blue-black coloration after mixing few drops of $0.1 \% \mathrm{FeCl}_{3}$ confirmed the existence of tannins [24].

\section{Quantitative determination of the chemical constituents Quantification of alkaloids}

Quantification of alkaloids was performed by following the method reported previously (22). Each fraction $(50 \mathrm{mg})$ was mixed with $200 \mathrm{ml}$ of acetic acid (10\%) in ethanol; the beaker was covered and incubated for $4 \mathrm{~h}$. The mixture was concentrated up to one third of its total volume. Ammonium hydroxide was added drop wise in the mixture until it formed precipitate. The precipitate was washed with ammonium hydroxide and then filtered. The filtrate (alkaloids) was calculated as percentage of the dried fraction.

\section{Quantification of tannins}

For quantification of tannins each fraction (50 mg) was suspended in $100 \mathrm{ml}$ of distilled water, it was shaken for $1 \mathrm{~h}$ in a mechanical shaker and then filtered. Each sample $(5 \mathrm{ml})$ was added with ferric chloride $(2 \mathrm{ml})$ in hydrochloric acid $(0.1 \mathrm{~N})$ and potassium ferricyanide $(0.008 \mathrm{M})$. Absorbance was taken at $120 \mathrm{~nm}$ within $10 \mathrm{~min}$ and tannins contents were calculated as percentage of the dried fraction (24).

\section{Quantification of saponins}

Methanol extract and each fraction (50 mg) were mixed in $100 \mathrm{ml}$ of ethanol (20\%). It was kept on heating for $4 \mathrm{~h}$ with continuous stirring at $55^{\circ} \mathrm{C}$, than diluted with diethyl ether $(20 \mathrm{ml})$ and washed with $5 \%$ sodium chloride. Saponins were estimated as percentage of the dried fraction (22).

\section{Estimation of leaf protein}

For the determination of leaf protein content, monobasic sodium phosphate $(16 \mathrm{ml})$ and dibasic sodium phosphate $(84 \mathrm{ml})$ was combined to get the desire $\mathrm{pH}(7.5)$ of phosphate buffer.

Reagent 1: Sodium carbonate (2 g), sodium chloride $(0.4 \mathrm{~g}) 0.1 \mathrm{~N}$ and $\mathrm{Na}-\mathrm{K}$ tartarate $1 \mathrm{~g}$ was dissolved in distilled water $(100 \mathrm{ml})$.

Reagent 2: Copper sulphate $0.5 \mathrm{~g}$ was mixed in distilled water $(100 \mathrm{ml})$.

Reagent 3: Solution A $(50 \mathrm{ml})$ and solution B $(1 \mathrm{ml})$ both were mixed in a flask. 
Reagent 4: Folin phenol reagent was added to distilled water (1:1 ratio).

Fresh leaves $(0.1 \mathrm{~g})$ were homogenized in $1 \mathrm{ml}$ of phosphate buffer ( $\mathrm{pH}$ 7.5). The homogenate was centrifuged for $10 \mathrm{~min}$ at $3000 \mathrm{rpm}$. The $0.1 \mathrm{ml}$ of supernatant was taken in a test tube and finally volume was raised by adding distilled water up to $1 \mathrm{ml}$. Reagent $\mathrm{D}(0.1 \mathrm{ml})$ was mixed after shaking for $10 \mathrm{~min}$. After 30 min of incubation, absorbance of each sample was taken at $650 \mathrm{~nm}$ and protein content was measured with help of standard (BSA) (23).

\section{Sugar estimation}

Fresh plant material was used to estimate the sugar content; plant material was homogenized and then treated with concentrated sulphuric acid. The sample was incubated for $4 \mathrm{~h}$ at $25^{\circ} \mathrm{C}$. Optical density of each sample was observed at $420 \mathrm{~nm}$ (24).

\section{Total phenolic content}

Briefly, a mixture was prepared by adding $9 \mathrm{ml}$ of distilled water and $1 \mathrm{ml}$ of each sample. To the mixture $1 \mathrm{ml}$ of Folin-Ciocalteu's phenol reagent was added followed by the addition of $10 \mathrm{ml}$ of $\mathrm{Na}_{2} \mathrm{CO}_{3}$ solution and total volume was made to $25 \mathrm{ml}$ by adding distilled water. The optical density was determined after $90 \mathrm{~min}$ at $750 \mathrm{~nm}$ at $23^{\circ} \mathrm{C}$. Quantity of total phenolics was determined as mg of gallic acid equivalent (GAE) per $\mathrm{g}$ of dried sample. For blank distilled water was used [25].

\section{Total flavonoid content}

According to this method [26], $0.3 \mathrm{ml}$ of the filtrate the extract and each fraction $(50 \mathrm{mg}$ ) in $10 \mathrm{ml}$ of $80 \%$ methanol was mixed with a reagent; $3.4 \mathrm{ml}$ of $30 \%$ methanol, $0.15 \mathrm{ml}$ of $\mathrm{NaNO}_{2}(0.5 \mathrm{M})$ and $0.15 \mathrm{ml}$ of $\mathrm{AlCl}_{3} \cdot 6 \mathrm{H}_{2} \mathrm{O}(0.3 \mathrm{M})$. Then $\mathrm{NaOH}$ was added properly mixed. Absorbance was recorded at $506 \mathrm{~nm}$ after $5 \mathrm{~min}$ of mixing. Total flavonoid content was calculated as $\mathrm{mg}$ of rutin equivalent per $\mathrm{g}$ of dried extract or fraction.

\section{In vitro antioxidant assays}

A stock solution $(1 \mathrm{mg} / \mathrm{ml})$ of the methanol extract and each fraction was prepared in 95\% methanol and diluted accordingly for various antioxidant and reducing assays. Antioxidant power of each assay was compared with the efficacy of standard chemicals.

\section{DPPH radical scavenging activity}

Antioxidant potential of the extract and each fraction was assessed by using 1,1-diphenyl 1-2-picryl-hydrazyl $(\mathrm{DPPH})$ assay [27]. DPPH $(2.4 \mathrm{mg})$ was dissolved in $100 \mathrm{ml}$ of methanol and diluted with methanol to obtain an absorbance of about $0.98( \pm 0.02)$ at $517 \mathrm{~nm}$. An aliquot of $0.01 \mathrm{ml}$ of the extract and each fraction at different concentrations of $25-250 \mu \mathrm{g} / \mathrm{ml}$ was added in $3 \mathrm{ml}$ of the DPPH solution. After incubation for $15 \mathrm{~min}$ in dark; absorbance of the mixture was determined at $517 \mathrm{~nm}$. Following formula was applied to determine the DPPH radical scavenging activity;

Percentage inhibition $=[($ control absorbance-sample absorbance $)$ $/($ control absorbance $)] \times 100$.

$\mathrm{IC}_{50}$ is the concentration value which scavenged 50\% of the DPPH radicals. Ascorbic acid and rutin were used as reference compounds $[28,29]$.

\section{Superoxide radical scavenging}

Procedure of Beauchamp and Fridovich [30] was followed to determine the scavenging potential of the extract and fractions with respect to superoxide radicals. Briefly, $0.5 \mathrm{ml}$ of $50 \mathrm{mM}$ phosphate buffer ( $\mathrm{pH} 7.6)$, $0.3 \mathrm{ml}$ of $50 \mathrm{mM}$ riboflavin, $0.25 \mathrm{ml}$ of $20 \mathrm{mM}$ phenazine methosulphate (PMS) and $0.1 \mathrm{ml}$ of $0.5 \mathrm{mM}$ nitro blue tetrazolium (NBT) were mixed, before the addition of $100 \mu \mathrm{l}$ of the methanol extract and each fraction at varying concentrations of $25-250 \mu \mathrm{g} / \mathrm{ml}$. Mixture was illuminated in the fluorescent light for $20 \mathrm{~min}$ and $560 \mathrm{~nm}$ wave length was used to record the absorbance of the mixture. The percent inhibition was calculated by using the following formula:

Percentage inhibition $=(1-$ absorbance of sample /absorbance of control) $\times 100$.

Reference compound used was ascorbic acid in this assay.

\section{Total antioxidant capacity}

Phosphomolybdate assay system was used to determine the total antioxidant activity of the methanol extract and various fractions [31]. To a reagent solution; sulphuric acid $(0.6 \mathrm{M})$, sodium phosphate $(28 \mathrm{mM})$ and ammonium molybdate $(4 \mathrm{mM}) ; 100 \mu \mathrm{l}$ of each sample was added and incubated at $95^{\circ} \mathrm{C}$ in a water bath for $90 \mathrm{~min}$. After cooling to room temperature; absorbance was recorded at $765 \mathrm{~nm}$ against reagent blank. Total antioxidant capacity of the ascorbic acid was also estimated for reference. The total antioxidant capacity was determined by using following formula:

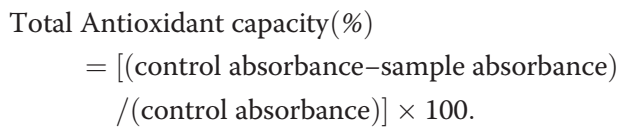

\section{Reducing assays}

\section{Hydroxyl radical scavenging}

A method described earlier was adapted to assess the hydroxyl radical scavenging ability of various samples [32]. 
Briefly, reagent solution was prepared by sequential addition of ferric chloride $(10 \mathrm{mM}), 0.25 \mathrm{ml}$ of 2-deoxyribose $(2.8 \mathrm{mM})$ in $50 \mathrm{mM}$ phosphate buffer $(\mathrm{pH} 7.4), 0.1 \mathrm{ml}$ of $1 \mathrm{mM}(1: 1 ; \mathrm{v} / \mathrm{v})$ EDTA solution and $0.1 \mathrm{ml}$ of $10 \mathrm{mM} \mathrm{H}_{2} \mathrm{O}_{2}$. A volume of $0.1 \mathrm{ml}$ of the extract and various fractions was individually added to $0.01 \mathrm{ml}$ of reagent solution. Then $0.1 \mathrm{ml}$ of ascorbate $(1 \mathrm{mM})$ was added and incubated at $37^{\circ} \mathrm{C}$ for $1 \mathrm{~h}$. In the mixture thiobarbituric acid (TBA) $0.5 \%$; $\mathrm{w} / \mathrm{v}$ in $1 \mathrm{ml}$ of $50 \mathrm{mM} \mathrm{NaOH}$ and $1 \mathrm{ml}$ of $10 \% \mathrm{w} / \mathrm{v}$ trichloroacetic acid (TCA) was added and cooled to room temperature after incubation in a boiling water bath for $15 \mathrm{~min}$. Intensity of chromogen was read at $532 \mathrm{~nm}$. The hydroxyl radical scavenging activity was estimated as;

Hydroxyl radical scavenging activity $(\%)$

$=(1-$ Abs.of sample $/$ Abs.of control $) \times 100$.

\section{Hydrogen peroxide scavenging}

Methods described previously [33-35] were followed to determine the ability of extract and various fractions to scavenge $\mathrm{H}_{2} \mathrm{O}_{2}$. Hydrogen peroxide $(2 \mathrm{mM})$ working solution was made by mixing with $50 \mathrm{mM}$ phosphate buffer (pH 7.4). Reaction mixture was prepared by the addition of $0.1 \mathrm{ml}$ of extract and each fraction with $0.4 \mathrm{ml}$ of $50 \mathrm{mM}$ phosphate buffer ( $\mathrm{pH} 7.4$ ) followed by the addition of $0.6 \mathrm{ml}$ of $50 \mathrm{mM} \mathrm{H}_{2} \mathrm{O}_{2}$ and allowed to stand for $10 \mathrm{~min}$. At $230 \mathrm{~nm}$ absorbance of the mixture was recorded. Following equation was used to determine the capacity to scavenge $\mathrm{H}_{2} \mathrm{O}_{2}$;

Hydrogen peroxide scavenging activity $(\%)$

$=(1-$ absorbance of sample $/$ absorbance of control $)$ $\times 100$

\section{ABTS radical scavenging}

Method of Re et al. [36] was used for the ABTS radical scavenging activity of the extract and each fraction. For the development of ABTS radicals potassium persulfate $(2.45 \mathrm{mM})$ solution was mixed with ABTS $(7 \mathrm{nM})$ and incubated overnight in the dark to get a dark colored solution. The standard solution of ABTS was diluted by the addition of $60 \%$ methanol to have an absorbance of $0.70( \pm 0.02)$ at $745 \mathrm{~nm}$ at $30^{\circ} \mathrm{C}$. An aliquot of $0.3 \mathrm{ml}$ of extract or fraction was mixed with $1 \mathrm{ml}$ of ABTS and absorbance was recorded after one minute. Reducing capacity was determined according to the formula:

$$
\begin{aligned}
\% \text { inhibition }= & {[(\text { control absorbance }- \text { sample absorbance })} \\
& /(\text { control absorbance })] \times 100 .
\end{aligned}
$$

\section{Reduction of $\mathrm{Fe}^{3+}$ to $\mathrm{Fe}^{2+}$}

Reducing capability of the extract and each fraction was estimated by following the method of Oyaizu [37]. A volume of $2 \mathrm{ml}$ of $0.2 \mathrm{M}$ phosphate buffer ( $\mathrm{pH}$ 6.6) and $2 \mathrm{ml}$ of potassium ferricyanide was mixed with $2 \mathrm{ml}$ of the extract and each fraction $(10 \mathrm{mg} / \mathrm{ml})$ and incubated for at $50^{\circ} \mathrm{C}$ for $20 \mathrm{~min}$. From the reaction mixture $2 \mathrm{ml}$ was taken after the addition of $2 \mathrm{ml}$ of 10\% TCA and was mixed with $0.4 \mathrm{ml}$ of $0.1 \%$ ferric chloride and $2 \mathrm{ml}$ of distilled water. After $10 \mathrm{~min}$ of incubation optical density of the chromogen formed was read at $700 \mathrm{~nm}$. High reducing power ability was associated with high absorbance values. Reducing power of ascorbic acid was considered as reference.

\section{In vitro anti-lipid peroxidation assay}

Standard method for estimation of TBARS was used to assay the degree of lipid peroxidation [38]. The study procedure for the animal care and experimentation was permitted by Ethical Committee of Quaid-i-Azam University Islamabad. From freshly excised liver of rat $10 x$ homogenate was made in cold phosphate buffer saline $(\mathrm{pH}$ 7.4). Extract and each fraction were added to $100 \mu \mathrm{l}$ of $(15 \mathrm{mM})$ ferrous sulphate followed by addition of $3 \mathrm{ml}$ of homogenate. After incubation for $30 \mathrm{~min} ; 0.1 \mathrm{ml}$ of this reaction mixture was mixed with $1.5 \mathrm{ml}$ of $10 \%$ TCA. After $10 \mathrm{~min}$ of incubation it was filtered and supernatant was added in a tube having $1.5 \mathrm{ml}$ of $0.67 \%$ TBA (in $50 \%$ acetic acid) and placed in a boiling water bath for $30 \mathrm{~min}$. Concentration of chromogen formed was measured at $535 \mathrm{~nm}$. Anti-lipid peroxidation was assessed by using the following formula:

$$
\% \text { Inhibition }=(\text { control-test }) / \text { control } \times 100
$$

\section{Anti-hemolytic activity}

Anti-hemolytic activity was assessed by following the spectrophotometric method [39]. From a normal healthy individual $5 \mathrm{ml}$ of blood was taken and centrifuged at $1500 \mathrm{rpm}$ for $3 \mathrm{~min}$. Pellet of blood was washed three times in sterile phosphate buffer saline solution ( $\mathrm{pH} 7.2)$. The pellet was re-suspended in normal $0.5 \%$ saline solution. A volume of $0.5 \mathrm{ml}$ of the extract and various fractions $(10,50,100,200,250 \mu \mathrm{g} / \mathrm{ml}$ in saline) were added in $0.5 \mathrm{ml}$ of cell suspension. After incubation the mixture at $37^{\circ} \mathrm{C}$ for $30 \mathrm{~min}$ it was centrifuged at $1500 \mathrm{rpm}$ for $10 \mathrm{~min}$. Anti-hemolytic activity was assessed by measuring the absorbance at $540 \mathrm{~nm}$. For positive and negative control distilled water and phosphate buffer saline were used respectively. The study protocol was in compliance with Helsinki Declaration.

\section{Statistical analysis}

In vitro and other parametric assays were performed in triplicate and results are shown as mean \pm SD. Antioxidant potential of different assays was determined as $\mathrm{IC}_{50}$ 
values by applying Graph pad prism 5-software. Statistical significance was determined among various treatments with one way ANOVA test. A statistical significance of $\mathrm{P}<0.05$ or $\mathrm{P}<0.01$ was considered to be significant.

\section{Results}

\section{Phytochemical analysis}

Phytochemical analysis of methanol extract of $M$. royleanus leaves indicated the existence of alkaloids, anthraquinones, cardiac glycosides, coumarins, flavonoids, saponins, phlobatannins, tannins and terpenoids. Saponins, phlobatannins and terpenoids were not determined in $n$-hexane fraction while alkaloids, coumarins, saponins, phlobatannins and terpenoids were not detected in chloroform fraction. Anthraquinones and cardiac glycosides were not detected in ethyl acetate and in $n$-butanol fraction respectively. Residual aqueous fraction depicted the existence of anthraquinones, coumarins, phlobatannins and tannins (Tables 1 and 2).

\section{Extraction yield}

The percentage extraction yield of methanol extract and its derived fractions is shown in Table 2. The extraction yield of methanol extract was $12.2 \pm 0.9 \%$ to that of the dry powder. Extraction yield of different fractions was obtained in descending order of residual aqueous $>$ ethyl acetate $>n$-butanol $>n$-hexane $>$ chloroform fraction. There was found a significant $(\mathrm{P}<0.05)$ difference for the extraction yield for all the fractions except nonsignificant $(P>0.05)$ difference was recorded for the extraction yield of $n$-hexane and $n$-butanol fraction.

\section{Estimation of total flavonoid and phenolic content}

Methanol extract showed the total phenolic content of $76.0 \pm 2.7 \mathrm{mg}$ gallic acid equivalent/g dried powder. Total phenolic content of various fractions was determined in the descending order of ethyl acetate $>n$-butanol $>n$-hexane $>$ residual aqueous $>$ chloroform fraction having significant $(\mathrm{P}<0.05)$ differences among themselves (Table 3). In case of total flavonoid content estimation, methanol extract exhibited the total flavonoid content of $63.5 \pm 1.84 \mathrm{mg}$ rutin equivalent/g dried fraction. Significant $(\mathrm{P}<0.05)$ difference was recorded in the descending order for; ethyl acetate $>n$-butanol $>n$-hexane $>$ residual aqueous $>$ chloroform fraction.

\section{Antioxidant assays DPPH radical scavenging activity}

DPPH radical scavenging activity of the $M$. royleanus is shown in Figure 1. In this study the methanol extract and various fractions dose dependently scavenged the DPPH radicals. $\mathrm{IC}_{50}$ values of $\mathrm{DPPH}$ radical scavenging ability of extract and its derived fractions can be ranked as ethyl acetate $<$ methanol $<n$-butanol $<n$-hexane $<$ residual aqueous $<$ chloroform fraction. $\mathrm{IC}_{50}$ value determined for ethyl acetate fraction, methanol extract and $n$-butanol were nonsignificantly different from each other (Table 4). However, the scavenging activities of all fractions were less $(\mathrm{P}<0.05)$ than those of standard compounds such as ascorbic acid and rutin.

\section{Superoxide radical scavenging activity}

Crude extract and its derived fractions showed a scavenging activity on superoxide radicals in a concentration dependent manner (Figure 2). $\mathrm{IC}_{50}$ values for superoxide scavenging activities were in order of ethyl acetate $<n$-butanol $<$ methanol $<n$-hexane $<$ residual aqueous $<$ chloroform fraction (Table 3). Ethyl acetate fraction exhibited the highest scavenging ability with $\mathrm{IC}_{50}$ value of $47.0 \pm 1.3 \mu \mathrm{g} / \mathrm{ml}$ followed by $n$-butanol fraction $\left(\mathrm{IC}_{50} 68.0 \pm 2.6 \mu \mathrm{g} / \mathrm{ml}\right)$ as compared to that of ascorbic acid $\left(\mathrm{IC}_{50} 34.0 \pm 0.6 \mu \mathrm{g} / \mathrm{ml}\right)$.

Table 1 Estimation of phytochemicals of extract and its fractions of $M$. royleanus leaves

\begin{tabular}{lcccccc}
\hline Phytochemical tests & $\begin{array}{c}\text { Methanol } \\
\text { extract }\end{array}$ & $\begin{array}{c}\text { n-hexane } \\
\text { fraction }\end{array}$ & $\begin{array}{c}\text { Chloroform } \\
\text { fraction }\end{array}$ & $\begin{array}{c}\text { Ethyl acetate } \\
\text { fraction }\end{array}$ & $\begin{array}{c}n \text {-butanol } \\
\text { fraction }\end{array}$ & $\begin{array}{c}\text { Residual aqueous } \\
\text { fraction }\end{array}$ \\
\hline Alkaloids & + & + & - & + & + & + \\
Anthraquinones & + & + & + & + & - & + \\
Cardiac glycosides & + & + & - & + & + & + \\
glycosides & + & + & + & + & + & + \\
Coumarins & + & + & - & + & + \\
Flavonoids & + & - & - & + & + \\
Saponins & + & - & + & + & + \\
Phlobatannins & + & + & - & + & + \\
Tannins & + & - & & + & + \\
Terpenoids & & & & + & +
\end{tabular}

+, present; -, absent. 
Table 2 Quantitative estimation of phytochemicals of extract and its fractions of $M$. royleanus leaves

\begin{tabular}{|c|c|c|c|c|c|}
\hline Samples & Saponins $\%$ & Tannins\% & Alkaloids\% & Protein (mg/g weight) & Sugar (mg/g weight) \\
\hline Methanol extract & $7.05 \pm 0.07$ & $5.57 \pm 0.02$ & $1.84 \pm 0.02$ & $6.65 \pm 0.45$ & $2.03 \pm 0.08$ \\
\hline$n$-hexane fraction & $6.4 \pm 0.2$ & $3.28 \pm 0.12$ & $0.74 \pm 0.12$ & $4.21 \pm 0.01$ & $1.01 \pm 0.03$ \\
\hline Chloroform fraction & $1.76 \pm 0.09$ & $5.27 \pm 0.14$ & $1.14 \pm 0.14$ & $0.65 \pm 0.11$ & $0.01 \pm 0.4$ \\
\hline Ethyl acetate fraction & $5.16 \pm 0.01$ & $4.89 \pm 0.2$ & $0.54 \pm 0.2$ & $4.56 \pm 0.03$ & $1.22 \pm 0.02$ \\
\hline$n$-butanol fraction & $5.82 \pm 0.04$ & $3.12 \pm 0.09$ & $0.63 \pm 0.09$ & $2.23 \pm 0.05$ & $1.09 \pm 0.21$ \\
\hline Residual aqueous fraction & $3.08 \pm 0.11$ & $4.12 \pm 0.08$ & $0.05 \pm 0.08$ & $1.21 \pm 0.04$ & $1.23 \pm 0.04$ \\
\hline
\end{tabular}

Each value is represented as mean $\pm S D(n=3)$.

\section{Phosphomolybdate assay (Total antioxidant capacity)}

The phosphomolybdate assay has been commonly used to determine the total antioxidant capacity of samples [40]. In this experiment Mo (VI) was reduced to Mo (V) by antioxidant potential of the extract and different fractions in a concentration dependent manner. The antioxidant capacity of the extract and different fractions was in the order of ethyl acetate $>n$-hexane $>$ methanol $>n$ butanol $>$ chloroform $>$ residual aqueous fraction. The $\mathrm{IC}_{50}$ values for the ethyl acetate and $n$-hexane fractions were $39.0 \pm 0.5 \mu \mathrm{g} / \mathrm{ml}$ and $40.0 \pm 0.7 \mu \mathrm{g} / \mathrm{ml}$, respectively, and were statistically $(\mathrm{P}>0.05)$ similar to the total antioxidant capacity of ascorbic acid (Table 4).

\section{Reducing assays}

\section{Hydroxyl radical scavenging}

The hydroxyl radical scavenging ability of different fractions can be ranked as ethyl acetate $>n$-hexane $>$ methanol $>n$-butanol $>$ chloroform $>$ residual aqueous fraction. Results showed that hydroxyl radical scavenging capacity was increased by increasing the concentration of extract and all fractions at $25-250 \mu \mathrm{g} / \mathrm{ml}$. The $\mathrm{IC}_{50}$ values of scavenging hydroxyl radicals for ethyl acetate fraction was $60.0 \pm 3.2 \mu \mathrm{g} / \mathrm{ml}$ while for residual aqueous fraction it was $>250 \mu \mathrm{g} / \mathrm{ml}$ (Table 5).

\section{Hydrogen peroxide scavenging}

Hydrogen peroxide scavenging activity determined in this study for the extract and different fractions of $M$. royleanus; were capable of scavenging hydrogen peroxide in a concentration dependent manner $(25-250 \mu \mathrm{g} / \mathrm{ml})$.
As compared for $\mathrm{IC}_{50}$ values, the hydrogen peroxide scavenging activities of methanol $(70.0 \pm 1.9 \mu \mathrm{g} / \mathrm{ml})$ and $n$-hexane fraction $(72.0 \pm 0.7 \mu \mathrm{g} / \mathrm{ml})$ were more $(\mathrm{P}<0.05)$ effective than that of chloroform $(>250 \mu \mathrm{g} / \mathrm{ml})$ fraction (Table 5). The potential of all the fractions to scavenge hydrogen peroxide as shown by $\mathrm{IC}_{50}$ values were significantly different $(\mathrm{P}<0.05)$ from the $\mathrm{IC}_{50}$ values obtained for standard compounds (ascorbic acid and rutin). The scavenging abilities on hydrogen peroxide were in order of methanol $>n$-hexane $>$ ethyl acetate $>$ $n$-butanol $>$ residual aqueous $>$ chloroform fraction.

\section{ABTS radical scavenging}

ABTS radical scavenging ability of the extract and different fractions can be ranked as $n$-butanol $>$ chloroform $>$ ethyl acetate $>$ residual aqueous $>$ methanol $>n$-hexane fraction. The scavenging ability of the extract and fractions for ABTS radicals was related with concentration of the tested samples. The $n$-butanol and chloroform fraction exhibited the highest scavenging potential when reacted with ABTS radicals as compared to the methanol and $n$-hexane fraction (Table 5 ). $\mathrm{IC}_{50}$ values of the extract and all fractions obtained were significantly $(\mathrm{P}>0.05)$ higher than that of the standard compounds.

\section{Reducing power assay}

In reducing power assay, the reduction of ferric cyanide complex to the ferrous form by donating an electron indicates the presence of reductants in the testing samples. It was observed that the reducing power of the extract and different fractions increased in a concentration

Table 3 Estimation of total phenolic, flavonoid and extraction yield of extract and fractions of $M$. royleanus leaves

\begin{tabular}{llll}
\hline Plant extract & $\begin{array}{l}\text { Total phenolics } \\
\text { (mg GAE/g of extract) }\end{array}$ & $\begin{array}{l}\text { Total flavonoid } \\
\text { (mg rutin equivalent/g of extract) }\end{array}$ \\
\hline Methanol extract & $76 \pm 2.7^{\mathrm{a}}$ & $63.5 \pm 1.84^{\mathrm{a}}$ & \multicolumn{1}{c}{ Extraction yield (\%) } \\
n-hexane fraction & $44.5 \pm 3.23^{\mathrm{d}}$ & $36.8 \pm 1.94^{\mathrm{d}}$ & $7.5 \pm 1.45^{\mathrm{d}}$ \\
Chloroform fraction & $6.8 \pm 3.93^{\mathrm{f}}$ & $9.3 \pm 1.76^{\mathrm{e}}$ & $3.4 \pm 0.28^{\mathrm{e}}$ \\
Ethyl acetate fraction & $62.3 \pm 2.77^{\mathrm{b}}$ & $60.9 \pm 1.83^{\mathrm{b}}$ & $5.9 \pm 1.11^{\mathrm{c}}$ \\
$n$-butanol fraction & $53 \pm 2.63^{\mathrm{c}}$ & $3.5 \pm 1.13^{\mathrm{c}}$ & $31.4 \pm 1.27^{\mathrm{d}}$
\end{tabular}

Each value is represented as mean \pm SD $(n=3)$. Values in the same column followed by a different letter $\left({ }^{a-f}\right)$ are significantly different $(P<0.05)$. 


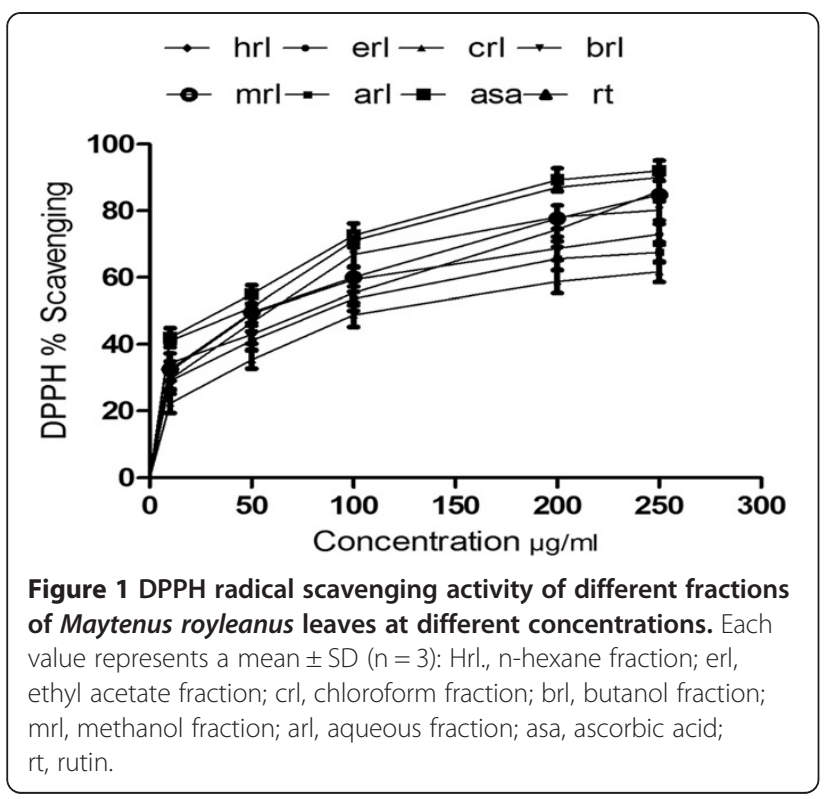

dependent manner. The reducing power of the extract and various fractions was in an order of $n$-butanol $>$ methanol $>$ chloroform $>n$-hexane $>$ ethyl acetate and residual aqueous fraction. The $n$-butanol and methanol fraction exhibited a good reducing power of $1.45 \pm$ $0.02 \mu \mathrm{g} / \mathrm{ml}$ and $1.24 \pm 0.04 \mu \mathrm{g} / \mathrm{ml}$ at $250 \mu \mathrm{g} / \mathrm{ml}$ (Table 6).

\section{Anti-lipid peroxidation assay}

On the basis of $\mathrm{IC}_{50}$ values pattern of anti-lipid peroxidation of the extract and various fractions can be arranged as ethyl acetate $>$ methanol $>$ residual aqueous $>$ $n$-hexane $>$ chloroform $>n$-butanol fraction. The results showed that approximately all the tested samples, dose dependently, inhibited lipid peroxidation. However, ethyl acetate fraction and methanol extract showed the highest scavenging potential while chloroform and $n$ butanol fraction showed the least anti-lipid peroxidation

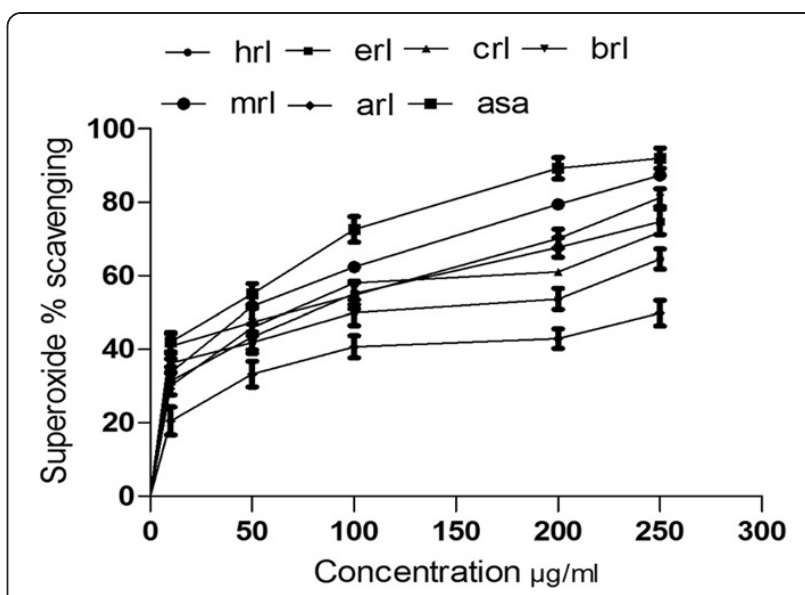

Figure 2 Superoxide radical scavenging activity of different fractions of Maytenus royleanus leaves at different concentrations. Each value represents a mean $\pm \mathrm{SD}(n=3)$ : Hrl., n-hexane fraction; erl, ethyl acetate fraction; $\mathrm{crl}$, chloroform fraction; brl, butanol fraction; mrl, methanol fraction; arl, aqueous fraction; asa, ascorbic acid; rt, rutin.

activity (Table 4). The $\mathrm{IC}_{50}$ values obtained for the extract and all fractions were significantly $(\mathrm{P}<0.05)$ higher from the $\mathrm{IC}_{50}$ value obtained for ascorbic acid.

\section{Anti-hemotylic activity}

Hemolytic activity of methanol extract of $M$. royleanus leaves and its various fractions was screened against normal human erythrocytes. Extract and different fractions exhibited differential pattern hemolytic effect towards human erythrocytes. Result indicated that the ethyl acetate fraction exhibited minimum hemolytic activity, where as aqueous fraction showed the highest hemolytic activity. Lysis of erythrocytes was found to be increased with an increase of extract or fraction concentration (Table 7).

Table 4 Antioxidant effects of extract and its fractions of $M$. royleanus leaves

\begin{tabular}{lllll}
\hline Extract/fraction & \multicolumn{3}{c}{$\mathbf{I C}_{\mathbf{5 0}}$ values } \\
\cline { 2 - 5 } & $\begin{array}{l}\text { Scavanging ability on DPPH } \\
\text { radicals }\end{array}$ & $\begin{array}{l}\text { Scavanging ability on } \\
\text { superoxide }\end{array}$ & $\begin{array}{l}\text { Phospho molybdate } \\
\text { Assay }\end{array}$ & $\begin{array}{l}\text { Inhibition of lipid } \\
\text { peroxidation }\end{array}$ \\
\hline Methanol extract & $55.02 \pm 0.5^{\mathrm{b}}$ & $69.80 \pm 2.6^{\mathrm{c}}$ & $46.10 \pm 35^{\mathrm{b}}$ & $79.12 \pm 0.5^{\mathrm{b}}$ \\
$n$-hexane fraction & $78.10 \pm 1.2^{\mathrm{c}}$ & $79.21 \pm 2.8^{\mathrm{d}}$ & $40.01 \pm 0.7^{\mathrm{a}}$ & $82.1 \pm 1.8^{\mathrm{c}}$ \\
Chloroform fraction & $109.8 \pm 3.2^{\mathrm{e}}$ & $250.10 \pm 0.5^{\mathrm{f}}$ & $90.22 \pm 1.2^{\mathrm{d}}$ & $130.21 \pm 1.4^{\mathrm{d}}$ \\
Ethyl acetate fraction & $55.01 \pm 2.3^{\mathrm{b}}$ & $47.01 \pm 1.3^{\mathrm{b}}$ & $39.02 \pm 0.5^{\mathrm{a}}$ & $76.32 \pm 0.3^{\mathrm{b}}$ \\
$n$-butanol fraction & $58.01 \pm 0.7^{\mathrm{b}}$ & $68.01 \pm 4.8^{\mathrm{c}}$ & $57.12 \pm 0.6^{\mathrm{c}}$ & $238.08 \pm 0.5^{\mathrm{e}}$ \\
Residual aqueous & $87.21 \pm 1.4^{\mathrm{d}}$ & $104.07 \pm 2.1^{\mathrm{e}}$ & $>250^{\mathrm{e}}$ & $80.01 \pm 1.4^{\mathrm{c}}$ \\
fraction & $34.10 \pm 0.8^{\mathrm{a}}$ & $34.00 \pm 0.6^{\mathrm{a}}$ & $38.40 \pm 2.4^{\mathrm{a}}$ & $35.9 \pm 0.7^{\mathrm{a}}$ \\
Ascorbic acid & $44.70 \pm 0.7^{\mathrm{a}}$ & - & - & - \\
Rutin & & & \\
\hline
\end{tabular}

Each value is represented as mean \pm SD $(n=3)$. Values in the same column followed by a different letter $\left({ }^{a-f}\right)$ are significantly different $(p<0.05)$. ${ }^{-}$not determined. 
Table 5 Reducing power effects of extract and its fractions of $M$. royleanus leaves

\begin{tabular}{llll}
\hline Extract/fraction & \multicolumn{1}{c}{$\mathbf{I C}_{\mathbf{5 0} \text { values }}$} \\
\cline { 2 - 4 } & $\begin{array}{l}\text { Scavenging ability on } \\
\text { hydroxyl radicals }\end{array}$ & $\begin{array}{l}\text { Scavenging ability on } \\
\text { hydrogen peroxide }\end{array}$ & $\begin{array}{l}\text { Scavenging ability on } \\
\text { ABTS radicals }\end{array}$ \\
\hline Methanol extract & $137.02 \pm 1.4^{\mathrm{d}}$ & $70.05 \pm 1.9^{\mathrm{b}}$ & $211.10 \pm 4.9^{\mathrm{f}}$ \\
$n$-hexane fraction & $98.10 \pm 0.5^{\mathrm{c}}$ & $72.02 \pm 0.7^{\mathrm{b}}$ & $>250^{\mathrm{g}}$ \\
Chloroform fraction & $>250^{\mathrm{f}}$ & $>250^{\mathrm{e}}$ & $65.01 \pm 0.7^{\mathrm{c}}$ \\
Ethyl acetate fraction & $60.01 \pm 3.2^{\mathrm{b}}$ & $89.00 \pm 0.1^{\mathrm{c}}$ & $78.00 \pm 1.2^{\mathrm{d}}$ \\
$n$-butanol fraction & $250.08 \pm 1.3^{\mathrm{e}}$ & $119.00 \pm 0.2^{\mathrm{d}}$ & $53.22 \pm 2.2^{\mathrm{b}}$ \\
Residual aqueous fraction & $>>250^{\mathrm{g}}$ & $123.02 \pm 1.3^{\mathrm{d}}$ & $116.11 \pm 0.8^{\mathrm{e}}$ \\
Ascorbic acid & $34.10 \pm 1.1^{\mathrm{a}}$ & $38.40 \pm 0.7^{\mathrm{a}}$ & $35.10 \pm 1.5^{\mathrm{a}}$ \\
Rutin & - & $45.01 \pm 1.5^{\mathrm{a}}$ & - \\
\hline
\end{tabular}

Each value is represented as mean $\pm S D(n=3)$. Values in the same column followed by a different letter $\left({ }^{(-g}\right)$ are significantly different $(p<0.05)$. not determined.

\section{Correlation between $\mathrm{IC}_{50}$ values with phenolic and flavonoid content}

In this study association of total phenolic and flavonoid content with $\mathrm{IC}_{50}$ values of different in vitro antioxidant assays was estimated (Table 8). A significant correlation of $\mathrm{IC}_{50}$ values of $\mathrm{DPPH}$, superoxide, hydrogen peroxide and anti-lipid peroxidation was established with total phenolic and flavonoid contents. However, a nonsignificant correlation was found between $\mathrm{IC}_{50}$ values of phosphomolybdate assay, ABTS and hydroxyl radical and total phenolic and flavonoid contents.

\section{Discussion}

Phytochemical screening provides basic information about medicinal importance of a plant extract. In this study evaluation for qualitative and quantitative estimation of the chemical constituents of M. royleanus extracts showed the presence of various secondary metabolites. Phytochemical analysis of methanol extract of $M$. royleanus leaves revealed the presence of bioactive constituents such as alkaloids, anthraquinones, cardiac glycosides, coumarins, flavonoids, saponins, phlobatannins, tannins and terpenoids. These constituents were separated away on the basis of polarity of different solvents in to different

Table 6 Reduction of $\mathrm{Fe}^{3+}$ to $\mathrm{Fe}^{2+}$ of extract and different fractions of $M$. royleanus leaves

\begin{tabular}{ll}
\hline Plant extracts & Reducing power $(\mathbf{7 0 0} \mathbf{~ n m}, \mathbf{2 5 0} \mathbf{~ g ~} / \mathbf{m l})$ \\
\hline Methanol extract & $1.55 \pm 0.04^{\mathrm{c}}$ \\
n-hexane fraction & $1.47 \pm 0.01^{\mathrm{c}}$ \\
Chloroform fraction & $0.95 \pm 0.01^{\mathrm{c}}$ \\
Ethyl acetate fraction & $1.50 \pm 0.03^{\mathrm{d}}$ \\
n-butanol fraction & $1.64 \pm 0.02^{\mathrm{b}}$ \\
Residual aqueous fraction & $1.03 \pm 0.11^{\mathrm{e}}$ \\
Ascorbic acid & $2.03 \pm 0.04^{\mathrm{a}}$ \\
\hline
\end{tabular}

Each value is represented as mean $\pm S D(n=3)$. Values in the same column followed by a different letter $\left({ }^{\mathrm{a}-\mathrm{e}}\right)$ are significantly different $(\mathrm{P}<0.05)$. fractions. Alkaloids and cardiac glycosides were absent in the chloroform fraction whereas flavonoids were not detected in the residual aqueous fraction. Ethyl acetate fraction was comprised of all the constituents except the anthraquinones. The biochemical investigation reports indicated the same composition of phytochemicals for the crude methanol extract of different plants [10,11,39].

The methanol extract of $M$. royleanus leaves were used to analyze the chemical composition by LC-MS. This technique was used to get a fingerprint of phytochemical composition of plant extract. As shown by the different compositions of the base peaks in the chromatograms, it is a complex mixture of different compounds such as phytoestrogens which are often found to be conjugated to one or more carbohydrate moieties and other polar groups (Figure 3). Further work is in progress to identify and isolate some of these compounds by elemental analysis and other analytical methods such as NMR spectroscopy or MS measurements.

Different species of Maytenus genus are used in traditional medicine for treatment of cancer [41] and for treatment of gastrointestinal diseases [42]. The biological activities of Maytenus species are considered to be due to the presence of different classes of secondary metabolites such as phenolic glucosides [43] flavonoids [44] and triterpenes. Pharmacological potential of Maytenus genus has been largely associated to the presence of triterpenes such as 3, 15-dioxo-21 $\alpha$-hydroxyfriedelane that was isolated from Maytenus robusta; showed antiulcerogenic activity [45]. Maytenfolic acid was isolated from Maytenus herterophylla and inhibited the growth of Candida albicans [46].

Quantitative determination of total flavonoid and total phenolic contents indicates that methanol extract possesses the highest concentration of total flavonoid and phenolic content. Similar findings have been reported where total phenolic and flavonoid contents are found in greater quantity in different plants $[10,11,40]$. The 
Table 7 Anti-hemolytic activity of extract and various fractions of $M$. royleanus leaves

\begin{tabular}{|c|c|c|c|c|c|c|c|}
\hline \multirow[t]{3}{*}{ Extract } & \multirow[t]{3}{*}{ Positive control $^{a}$} & \multirow[t]{3}{*}{ Negative control $^{b}$} & \multicolumn{5}{|c|}{ Optical density ${ }^{c}$} \\
\hline & & & \multicolumn{5}{|c|}{ Concentration $\mu \mathrm{g} / \mathrm{ml}$} \\
\hline & & & 10 & 50 & 100 & 200 & 250 \\
\hline & $0.41 \pm 0.01$ & $1.07 \pm 0.02$ & & & & & \\
\hline \multirow[t]{2}{*}{ Methanol extract } & & & $1.03 \pm 0.02^{a}$ & $0.94 \pm 0.02^{b}$ & $0.88 \pm 0.04^{b}$ & $0.84 \pm 0.02^{b}$ & $0.78 \pm 0.03^{b}$ \\
\hline & $0.41 \pm 0.01$ & $1.07 \pm 0.02$ & & & & & \\
\hline \multirow[t]{2}{*}{$n$-hexane fraction } & & & $1.01 \pm 0.03^{\mathrm{a}}$ & $0.98 \pm 0.03^{a}$ & $0.87 \pm 0.02^{b}$ & $0.82 \pm 0.04^{b}$ & $0.76 \pm 0.04^{b}$ \\
\hline & $0.41 \pm 0.01$ & $1.07 \pm 0.02$ & & & & & \\
\hline \multirow[t]{2}{*}{ Chloroform fraction } & & & $0.94 \pm 0.04^{b}$ & $0.76 \pm 0.03^{c}$ & $0.74 \pm 0.03^{c}$ & $0.68 \pm 0.03^{d}$ & $0.64 \pm 0.03^{c}$ \\
\hline & $0.41 \pm 0.01$ & $1.07 \pm 0.02$ & & & & & \\
\hline \multirow[t]{2}{*}{ Ethyl acetate fraction } & & & $1.03 \pm 0.02^{a}$ & $0.98 \pm 0.04^{a}$ & $0.96 \pm 0.04^{a}$ & $0.92 \pm 0.04^{a}$ & $0.85 \pm 0.05^{a}$ \\
\hline & $0.41 \pm 0.01$ & $1.07 \pm 0.02$ & & & & & \\
\hline \multirow[t]{2}{*}{$n$-butanol fraction } & & & $0.87 \pm 0.03^{c}$ & $0.74 \pm 0.04^{c}$ & $0.70 \pm 0.04^{c}$ & $0.65 \pm 0.04^{c}$ & $0.58 \pm 0.04^{d}$ \\
\hline & $0.41 \pm 0.01$ & $1.07 \pm 0.02$ & & & & & \\
\hline Residual aqueous fraction & & & $0.81 \pm 0.02^{d}$ & $0.76 \pm 0.02^{c}$ & $0.71 \pm 0.02^{c}$ & $0.64 \pm 0.03^{c}$ & $0.54 \pm 0.03^{e}$ \\
\hline
\end{tabular}

Each value is represented as mean \pm SE $(n=3)$. Values in the same column followed by a different letter $\left({ }^{a-e}\right)$ are significantly different $(p<0.05)$.

${ }^{a}$ Water replaced extract/fractions to serve as a positive control since this treatment results in $100 \%$ hemolysis.

${ }^{\mathrm{b}}$ Phosphate buffered saline replaced extract/fraction to serve as a negative control since this treatment results in $0 \%$ hemolysis.

c Lower values are associated with increased cell lysis.

chemical complexity of extract/fraction, often a mixture of varied compounds; having different functional groups, polarity and chemical behavior, could lead to diverse results, depending on the test employed. The solvents such as methanol, ethyl acetate and $n$-butanol are found superior in concentrating the phenolics from $M$. royleanus. It has been reported that rich flavonoid and phenolic plants could be a vital source of therapeutic potential against the oxidative damages $[12,13,47]$.

The scavenging effect of the extract and various fractions of $M$. royleanus leaves against DPPH radicals varied a great deal indicating that scavenging activities are related to the electron transfer/donating ability. The extract and all the fractions exhibited inferior $\mathrm{IC}_{50}$ values for DPPH radical scavenging activity as compared to the ascorbic acid. However, methanol extract and ethyl acetate fraction exhibit comparatively high antioxidant capacity as against the other fractions; suggesting the presence of free radical inhibitors acting possibly as primary antioxidants. Some of the pharmacological effects could be attributed due to these compounds.

Superoxide radical scavenging activity of different fractions was increased dose dependently in this study. Low level of $\mathrm{IC}_{50}$ values suggested that the chemical constituents found in methanol extract and its fractions are potent scavengers of superoxide radical at low concentration. Superoxide is one of the precursors of hydroxyl or singlet oxygen species, and also can propagate other free radicals, induces intricate process of lipid peroxidation resulting in membranous system damage and cellular injuries. The

Table 8 Correlation of total phenolics and flavonoids content with antioxidant assays of the extract and fractions of $M$. royleanus leaves

\begin{tabular}{|c|c|c|}
\hline \multirow[t]{2}{*}{ Assays } & \multicolumn{2}{|c|}{ Correlation $\mathrm{R}^{2}$} \\
\hline & Phenolics & Flavonoids \\
\hline$\overline{I C_{50} \text { of DPPH radical scavenging potential }}$ & $0.9256^{b}$ & $0.9812^{b}$ \\
\hline$I_{50}$ of superoxide radical scavenging potential & $0.7379^{a}$ & $0.7905^{a}$ \\
\hline $\mathrm{I}_{50}$ of total antioxidant capacity & 0.2568 & 0.1892 \\
\hline $\mathrm{I}_{50}$ of hydroxyl radical scavenging potential & 0.3843 & 0.3181 \\
\hline$I C_{50}$ of hydrogen peroxide radical scavenging potential & $0.7240^{\mathrm{a}}$ & $0.6718^{\mathrm{a}}$ \\
\hline$I_{50}$ of $A B T S$ radical scavenging potential & 0.1285 & 0.0354 \\
\hline$I_{50}$ of inhibition of lipid peroxidation & $0.6542^{\mathrm{a}}$ & $0.6587^{\mathrm{a}}$ \\
\hline
\end{tabular}

Methanol extract and its fractions of $M$. royleanus were used in correlation.

$a, b$ indicate significance at $P<0.05 \& P<0.01$ respectively. 

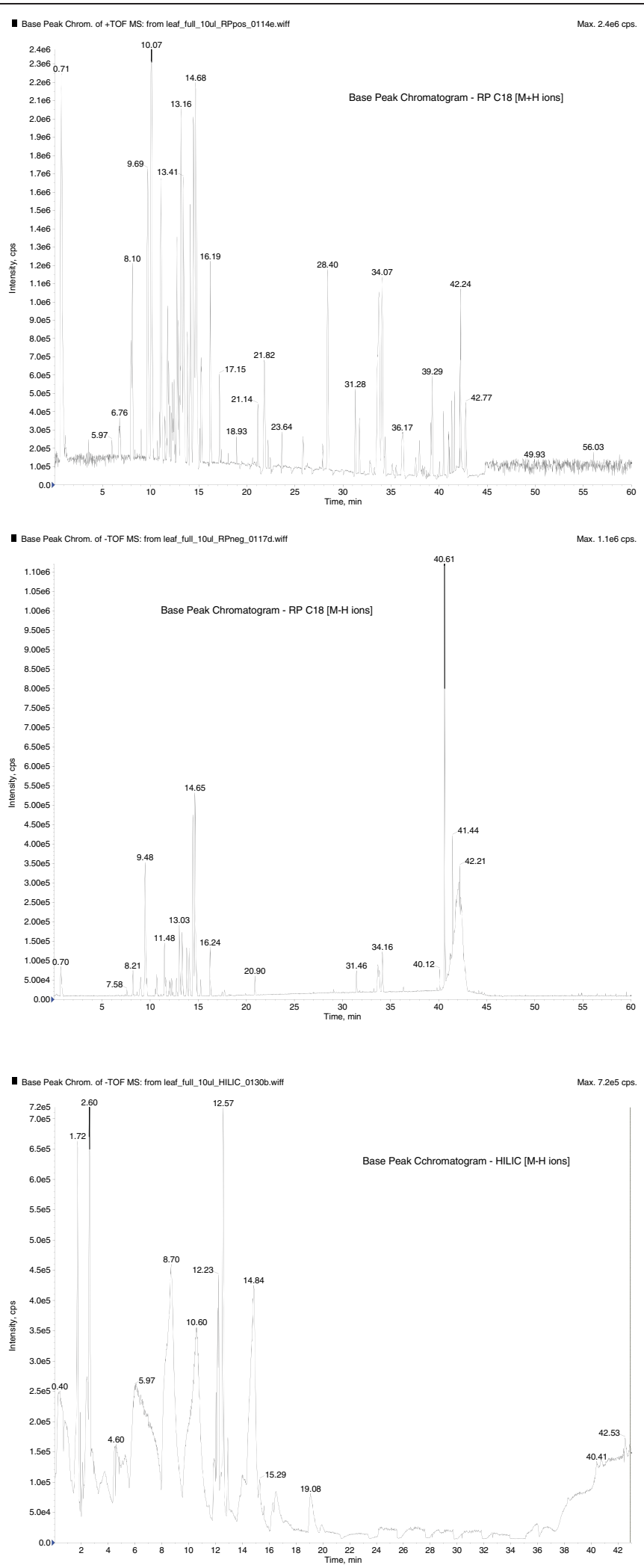

Figure 3 LC-MS of methanol extract of $M$. royleanus, 1, Base peak chromatogram - RP C18 (M + H ions) 300 features. 2, Base peak chromatogram - RP C18 (M-H ions) 59 features. 3, Base peak chromatogram - HILIC (M-H lons) 164 features. 
strong electron quenching activity of the extract and fractions could be due to the antioxidant compounds such as flavonoids and phenolic contents that enable to scavenge the oxidation of biological macromolecules $[10,11]$.

Ethyl acetate fraction of $M$. royleanus leaves depicted the highest level of total antioxidant capacity in the present investigation. It is suggested that many flavonoid and polyphenolics found in medicinal plants contribute significantly to the phosphomolybdate scavenging activity.

Antioxidant potential of extract or fraction is directly related to the scavenging of hydroxyl radical and consequently the inhibition of lipid peroxidation [47]. Generation of lipid hydroperoxides can cause damage to every molecule of the biological system and have the capacity to bind with DNA causing strand breaks, carcinogenesis and mutation [48]. The erythrocytes intrinsically are more prone to peroxidation due to the heavy accumulation of polyunsaturated fatty acids and haemoglobin. During respiration erythrocytes are continuously exposed to high tension of oxygen, which can induce oxidative damage [49]. Further, exposure of erythrocytes to toxicants leads to the generation of free radicals resulting in potential damages to the membranes and consequently hemolysis [50]. Extract and fractions used in this experiment exhibit the scavenging of hydroxyl radicals suggesting the presence of primary antioxidants which possess anti hemolytic as well as anti-lipid peroxidation potential.

Hydrogen peroxide itself is not very toxic to the cellular system; sometimes it becomes injurious as it is directly involved in the generation of hydroxyl radicals, act as free reactive oxygen species [11]. In this study methanol extract and its derived fractions such as $n$-hexane and ethyl acetate have moderate potential to scavenge the hydrogen peroxide potential hazard indicating the antioxidant capacity of the plant.

ABTS radical scavenging ability of the extract and different fractions exhibited a dose dependent response. Recent studies have shown that polyphenolics such as catechin, rutin and their derivatives more effectively scavenge the ABTS radicals [51]. Highest ABTS radical scavenging potential was shown by the $n$-butanol fraction indicating more accumulation of polyphenolics in this fraction.

In the reducing power assay the antioxidants donate an electron to stabilize the radicals and also break the free radical chain reaction [52]. The ability of fractions to exhibit the reducing power in this investigation may be related with the presence of antioxidant phytochemicals.

Maytenus royleanus possesses diverse antioxidant compounds as depicted by the antioxidant activities of different fractions. A strong correlation of $\mathrm{IC}_{50}$ values of antioxidant assays; DPPH, superoxide and hydrogen peroxide; with phenolic and flavonoids content of $M$. royleanus was exhibited in this study. However, nonsignificant correlation was found for $\mathrm{IC}_{50}$ values of total antioxidant capacity, ABTS and hydroxyl radical scavenging potential with flavonoid and phenolic contents. These results indicate that flavonoid and phenolics can be the major contributors for the antioxidant activity observed for the M. royleanus leaves extract and its fractions. These fractions may be exploited for the antioxidant potential of this plant.

\section{Conclusions}

Strong antioxidant capacity of the extract and its derived fractions for different in vitro antioxidant assays may be related with the antioxidant constituents such as flavonoid, phenolic, tannins and terpenoids in this plant. These results suggested the use of ethyl acetate fraction as primary antioxidant therapeutic source.

\section{Competing interest}

The authors declare that they have no competing interests.

\section{Authors' contributions}

MS has made substantial contribution to acquisition of data, analysis, drafting of the manuscript. MRK has made substantial contribution to conception and design, interpretation of data, drafting and revising the manuscript for intellectual content. NS participated in the design and collection of data and analysis. All authors read and approved the final manuscript.

\section{Acknowledgement}

We thank Higher Education Commission (HEC) of Pakistan for providing funds to this project.

Received: 11 January 2013 Accepted: 12 June 2013

Published: 22 June 2013

\section{References}

1. Ivanova D, Gerova D, Chervenkov T, Yankova T: Polyphenols and antioxidant capacity of Bulgarian medicinal plants. J Ethnopharmacol 2005, 97:145-150.

2. Gulcin I: Antioxidant activity of food constituents-An overview. Arch Toxicol 2012, 86(3):339-345.

3. Gulcin I, Beydemir S: Phenolic compounds as antioxidants: Carbonic anhydrase isoenzymes inhibitors. Mini Rev Med Chem 2013, 13(3):408-430

4. Balasundram N, Sundram K, Sammar S: Phenolic compounds in plants and agri-industrial by-products: Antioxidant activity, occurrence, and potential uses. Food Chem 2006, 68:191-203.

5. Aruoma IO, Cuppette SL: Antioxidant methodology in vivo and in vitro concept. Illinois: AOAS press; 1997.

6. Marchand LL: Cancer preventive affects of flavonoids: a review. Biomed Pharmacother 2002, 56:296-301.

7. Khan MR, Rizvi W, Khan GN, Khan RA, Shaheen S: Carbon tetrachlorideinduced nephrotoxicity in rats: protective role of Digera muricata. J Ethnopharmacol 2009, 122:91-99.

8. Khan RA, Khan MR, Sahreen S: Evaluation of Launea procumbens use in renal disorders: a rat model. J Ethnopharmacol 2010, 128:452-461.

9. Khan MR, Haroon J, Khan RA, Bokhari J, Rashid U: Prevention of $\mathrm{KBrO}_{3}$ induced cardiotoxicity by Sonchus asper in rat. J Med Plants Res 2011, 5:2514-2520.

10. Sahreen S, Khan MR, Khan RA: Evaluation of antioxidant activities of various solvent extracts of Carissa opaca fruits. Food Chem 2010, 122:1205-1211.

11. Sahreen S, Khan MR, Khan RA: Phenolic compounds and antioxidant activities of Rumex hastatus D. Don. Leaves. J Med Plants Res 2011, 5:2755-2765. 
12. Bursal E, Koksal E, Gulcin I, Bilsel G, Goren AC: Antioxidant activity and polyphenol content of cherry stem (Cerasus avium L.) determined by LCMS/MS. Food Res Int 2013, 51(1):66-74.

13. Gulcin I, Topal F, Cakmakc R, Bilsel M, Goren AC, Erdogan U: Pomological features, nutritional quality, polyphenol content analysis and antioxidant properties of domesticated and three wild ecotype forms of raspberries (Rubus idaeus L.). J Food Sci 2011, 76(4):C585-C593.

14. Ellof JN: Which extract should be used for the screening and isolation of antimicrobial components from plant. J Ethnopharmacol 1998, 60:1-8.

15. Middleton E Jr, Kandaswami C, Theoharides TC: The effects of plant flavonoids on mammalian cells: implications for inflammation, heart disease and cancer. Pharmacol Rev 2000, 52:673-751.

16. Velioglu YS, Mazza G, Gao L, Oomah BD: Antioxidant activity and total phenolics in selected fruits, vegetables and grain products. J Agri Food Chem 1998, 46:4113-4117.

17. Gulcin I, Kufrevioglu OI, Oktay M, Buyukokuroglu ME: Antioxidant, antimicrobial, antiulcer and analgesic activities of nettle (Urtica dioica L.). J Ethnopharmacol 2004, 90:205-215.

18. Gulcin I, Tel AZ, Kirecci E: Antioxidant, antimicrobial, antifungal and antiradical activities of Cyclotrichium niveum (Boiss.) Manden and Scheng. Int J Food Prop 2008, 11(2):450-471.

19. Nasir ASI: Flora of West Pakistan. No. 100. Karachi: Feroz sons; 1977:1.

20. Samin J, Khan MA, Din SU, Murad W, Hussain M, Ghani A: Herbal remedies used for gastrointestinal disorders in Kaghan Valley, NWFP, Pakistan. Pak J Weed Sci Res 2008, 14:169-200.

21. Kil HY, Seong ES, Ghimire BK, Chung IM, Kwon SS, Goh EJ, Hoe K, Kim MJ, Lim JD, Lee D, Yu CY: Antioxidant and antimicrobial activities of crude Sorghum extract. Food Chem 2009, 115:1234-1239.

22. Harborne JB: Phytochemical methods. London: London Chapman and Hall, Ltd; 1973:49-188.

23. Trease GE, Evans WC: Pharmacognosy. London: Brailliar Tiridel Can Macmillian Publishers; 1989:11.

24. Sofowora AE: Medicinal plants and traditional medicine in Africa, Volume 2. Ibadan, Nigeria: Spectrum books Ltd; 1993:289.

25. Kim DO, Jeong SW, Lee CY: Antioxidant capacity of phenolic phytochemicals from various cultivars of plums. Food Chem 2003, 81:321-326

26. Brand-Williams W, Cuvelier ME, Berset C: Use of free radical method to evaluate antioxidant activity. Lebensmittel-Wissenschaftund-Technol 1995, 28:25-30.

27. Yong SP, Soon TJ, Seong GK, Buk GH, Patricia AA, Fernando T: Antioxidant and proteins in ethylene-treated kiwifruits. Food Chem 2008, 107:640-648.

28. Gulcin I: Antioxidant properties of resveratrol: A structure-activity insight. Innov Food Sci Emerg Technol 2010, 11:210-218.

29. Gulcin I: Antioxidant activity of L-Adrenaline: An activity-structure insight. Chem Biol Interact 2009, 179(2-3):71-80

30. Beauchamp C, Fridovich I: Superoxide dismutase: improved assays and an assay applicable to acrylamide gels. Anal Biochem 1971, 1971(44):276-277.

31. Umamaheswari $M$, Chatterjee TK: In vitro antioxidant activities of the fractions of Coccinnia grandis L. leaf extract. Afr J Trad Compl Altern Med 2008, 5:61-73

32. Halliwell B, Gutteridge JMC: Formation of thiobarbituric acid reactive substances from deoxyribose in the presence of iron salts: the role of superoxide and hydroxyl radicals. FEBS Lett 1981, 128:347-352.

33. Ruch RJ, Cheng SJ, Klaunig JE: Prevention of cytotoxicity and inhibition of intercellular communication by antioxidant catechins isolated from Chinese green tea. Carcinogen 1989, 10:1003-1008.

34. Gulcin I, Buyukokuroglu ME, Kufrevioglu Ol: Metal chelating and hydrogen peroxide scavenging effects of melatonin. J Pineal Res 2003, 34:278-281.

35. Oktay M, Gulcin I, Kufrevioglu Ol: Determination of in vitro antioxidant activity of fennel (Foeniculum vulgare) seed extracts. Lebensm Wiss Technol 2003, 36(2):263-271.

36. Re R, Pellegrini N, Proteggente A, Pannala A, Yang M, Rice-Evans C: Antioxidant activity applying an improved ABTS radical cation decolorisation assay. Free Radical Bio Med 1999, 26:1231-1237.

37. Oyaizu M: Antioxidant activity of browning products of glucosamine fractionated by organic solvent and thin layer chromatography. Nippon Shokulin Kogyo Gakkaishi 1986, 35:771-775.

38. Ohkawa H, Ohishi N, Yagi K: Assay for lipid peroxides in animal tissues by thiobarbituric acid reaction. Anal Biochem 1979, 95:351-358.
39. Yang $Z G$, Sun $H X$, Fang WH: Haemolytic activities and adjuvant effect of Astragalus membranaceus saponins (AMS) on the immune responses to ovalbumin in mice. Vaccine 2005, 23:5196-5203

40. Prieto P, Pineda M, Aguliar M: Spectrophotometric quantitation of antioxidant capacity through the formation of Phosphomolybdenum complex: Specific application to the determination of vitamin E. Anal Biochem 1999, 269:337-341.

41. Khan RA, Khan MR, Sahreen S, Ahmed M: Evaluation of phenolic contents and antioxidant activity of various solvent extracts of Sonchus asper (L.) Hill. Chem Cent J 2012, 6:12.

42. Schaneberg BT, Green DK, Sneden AT: Dihydroagarofuran sesquiterpene alkaloids from Maytenus putterlickoides. J Nat Prod 2001, 64:624-626.

43. Cordeiro PJM, Vilegas JHY, Lancas FM: HRGC-MS analysis of terpenoids from Maytenus ilicifolia and Maytenus aquifolium ("Espinheira Santa"). J Braz Chem Soc 1999, 10:523-526.

44. Sannomiya M, Vilegas W, Ratrelli L, Pizza C: A flavonoids glycoside from Maytenus aquifolium. Phytochemistry 1998, 49:237-239.

45. Da Silva MS, De Sousa DP, Medeiros VM, Folly MAB, Tavares JF, BarbosaFilho JM: Alkaloid, flavonoids and pentacyclic triterpenoids of Maytenus obtusifolia Mart. Biochem Syst Ecol 2008, 36:500-503.

46. Andrade SF, da Silva Filho AA, de O Resende D, Silva ML, Cunha WR, Nanayakkara NP, Bastos JK: Antileishmanial, antimalarial and antimicrobial activities of the extract and isolated compounds from Austroplenckia populnea (Celastraceae). Z Naturforsch C 2008, 63:497-502.

47. Orabi KY, Al-Qasoumi SI, El-Qlemy MM, Mossa JS, Muhammad I: (Dihydroagarofuran alkaloid and triterpenes from Maytenus heterophylla and Maytenus arbutifolia. Phytochemistry 2001, 58:475-480.

48. Sharififar F, Dehghan-nudeh GH, Mirtajaldini M: Major flavonoids with antioxidant activity from Teucrium polium L. Food Chem 2009, 112:885-888.

49. Babu BH, Shylesh BS, Padikkala J: Antioxidant and hepatoprotective effect of Alanthus icicifocus. Fitoterapia 2001, 72:272-277.

50. Chakraborty D, Verma RJ: Ameliorative effect of Emblica officinalis aqueous extract against ochratoxin - induced lipid peroxidation in the kidney and liver of mice. Int J Occup Med Environ Health 2010, 23:1-11.

51. Rahimtula AD, Bereziat JC, Bussacchini-Griot V, Bartsch H: Lipid peroxidation as a possible cause of ochratoxin A toxicity. Biochem Pharmacol 1988, 37:4469-4477.

52. Niki E: Antioxidants in relation to lipid peroxidation. Chem Phys Lipids 1982, 44:227-253

\section{doi:10.1186/1472-6882-13-143}

Cite this article as: Shabbir et al:: Assessment of phytochemicals, antioxidant, anti-lipid peroxidation and anti-hemolytic activity of extract and various fractions of Maytenus royleanus leaves. BMC Complementary and Alternative Medicine 2013 13:143.

\section{Submit your next manuscript to BioMed Central and take full advantage of:}

- Convenient online submission

- Thorough peer review

- No space constraints or color figure charges

- Immediate publication on acceptance

- Inclusion in PubMed, CAS, Scopus and Google Scholar

- Research which is freely available for redistribution 